\title{
Contributors
}

\author{
Dennis Arnold
}

Assistant Professor (tenured), Department of Human Geography, Planning and International Development, University of Amsterdam, The Netherlands.

\section{Geoffrey Aung}

$\mathrm{PhD}$ Candidate, Department of Anthropology, Columbia University, USA.

James Brown

Lecturer, School of Geography, Queen Mary University of London, United Kingdom.

\section{Stephen Campbell}

Assistant Professor, School of Social Sciences, Nanyang Technological University, Singapore, and Research Fellow, Department of Social Anthropology, University of Bergen, Norway.

\section{Michela Cerimele}

Research Fellow, Department of Humanities and Social Sciences, University of Naples L'Orientale, Italy

\section{Pietro P. Masina}

Associate Professor of History and Institutions of Asia, University of Naples L'Orientale, Italy

$$
\text { Jinyoung Park }
$$

$\mathrm{PhD}$ Candidate, International and Comparative Labor, Cornell University, USA. 